\title{
NTRK3 wt Allele
}

National Cancer Institute

\section{Source}

National Cancer Institute. NTRK3 wt Allele. NCI Thesaurus. Code C52201.

Human NTRK3 wild-type allele is located within $15 q 25$ and is approximately $380 \mathrm{~kb}$ in length. This allele, which encodes NT-3 growth factor receptor protein, is involved in MAPK signal transduction and cellular differentiation. The allele may also play a role in the development of proprioceptive neurons. Mutations in the gene have been associated with medulloblastomas, secretory breast carcinomas and other cancers. 